\title{
Oxygen-Ozone $\left(\mathrm{O}_{2}-\mathrm{O}_{3}\right)$ Therapy in Peripheral Arterial Disease (PAD): A Review Study
}

This article was published in the following Dove Press journal:

Therapeutics and Clinical Risk Management

\section{Hanna Juchniewicz (D) Anna Lubkowska (D)}

Department of Functional Diagnostics and Physical Medicine, Faculty of Health Sciences, Pomeranian Medical University in Szczecin, Szczecin, Poland
Correspondence: Hanna Juchniewicz Department of Functional Diagnostics and Physical Medicine, Faculty of Health Sciences, Pomeranian Medical University in Szczecin, Zolnierska 54, Szczecin 7I210, Poland

Tel +48693833737

Email h.a.juchniewicz@gmail.com

\begin{abstract}
The purpose of this study is to review the current knowledge of oxygen-ozone $\left(\mathrm{O}_{2}-\mathrm{O}_{3}\right)$ therapy and its effects on peripheral artery disease (PAD) risk factors, symptoms, as well as on PAD patients' quality of life. From the in vitro studies, it has been concluded that the oxygen-ozone therapy exerts a positive effect on the platelet aggregation, cell remodeling, cytoskeletal elements organization and mitochondria structure. In animal studies, it has been shown that the $\mathrm{O}_{2}-\mathrm{O}_{3}$ therapy is an effective method in hypertension, and it diminishes the hypoxia state of various tissues. Clinical studies have provided evidence on the oxygenozone therapy effectiveness in low perfusion syndromes and hyperglycemia, as well as conditions with oxidative stress and inflammation. The oxygen-ozone therapy promotes faster recovery and enhances healing processes. It appears to be an effective adjunctive therapy in preventing peripheral artery disease complications such as occurrence of cardiovascular event, amputation or other extreme surgical solutions. It has been concluded that the $\mathrm{O}_{2}-\mathrm{O}_{3}$ therapy improves the quality of life of PAD patients. The oxygen-ozone therapy appears to have no adverse events or side effects. Moreover, it is very cost-effective, as standard treatment costs can be reduced by $25 \%$. Easy clinical protocols allow the implementation of oxygen-ozone therapy into the usual care of PAD patients. Finally, the $\mathrm{O}_{2}-\mathrm{O}_{3}$ therapy may be meaningful especially for older patients and patients who are not eligible for standard revascularization.
\end{abstract}

Keywords: amputation, diabetes mellitus, oxidative stress, wound healing

\section{Introduction}

A burden of peripheral arterial disease (PAD) prevalence has been observed over the last decade. Globally in 2010, about 202 million people were diagnosed with PAD. ${ }^{1}$ PAD is now the third most common cause of death from cardiovascular diseases, while in the first two places, there are coronary heart diseases and stroke. Statistical data from 1990 and 2010 reveal that the prevalence of PAD greatly increased among men. On the other hand, the number of PAD-related deaths is much more frequent among women. Similarly, in 2010 women experienced a greater level of disability in comparison with 1990. PAD patients have numerous symptoms lowering their quality of life. Intermittent claudication concerns $10-20 \%$ of patients, while $50 \%$ of them have atypical leg symptoms. ${ }^{2}$ Social and economic consequences of PAD need to be acknowledged. There is a great need for developing global prevention programs, as well as cost-effective treatments and management policies.

The oxygen-ozone $\left(\mathrm{O}_{2}-\mathrm{O}_{3}\right)$ therapy has been proposed as one of the treatments that may bring health and quality of life-related benefits for patients with hypoxic 
syndromes and diabetes mellitus. The $\mathrm{O}_{2}-\mathrm{O}_{3}$ therapy has been evaluated as a method for wound disinfection as well as treatment of dental caries and diabetes mellitus. ${ }^{3-5}$ However, looking at the available literature, a need to review the evidence of the effectiveness of the ozone therapy on the peripheral artery disease appears necessary.

The purpose of this study is to summarize current knowledge of the oxygen-ozone therapy and its effects on peripheral artery disease risk factors, symptoms, as well as on PAD patients' quality of life. Prospective, controlled studies provide evidence that through altering risk factors, the peripheral artery disease development and a course of disease can be altered. ${ }^{6}$ In the following section PAD risk factors, that can be altered by a treatment, will be discussed. The medical importance of the oxygenozone therapy will be explained as well. The paper will go onto question if the $\mathrm{O}_{2}-\mathrm{O}_{3}$ therapy is an effective method of altering PAD risk factors will be addressed. At first, the evidence from in vitro studies will be reviewed, and then evidence coming from animal studies will be evaluated. Of the three original methods, it is the clinical trials that provide the greatest insight and will be discussed at length.

\section{Methodology}

Relevant studies have been identified through the search in the Medline database up to November 2018. Three types of studies have been in the area of interest: in vitro studies, animal studies, and randomized clinical trials. The intervention needed to include oxygen-ozone therapy in order to assess the effectiveness of the treatment, the $\mathrm{O}_{2}-\mathrm{O}_{3}$ therapy compared with sham therapy, the $\mathrm{O}_{2}-\mathrm{O}_{3}$ therapy compared with any other intervention or the $\mathrm{O}_{2}-\mathrm{O}_{3}$ therapy combined with conventional treatment compared with any other intervention. The primary outcomes needed to be concerned about PAD risk factors, ischemic damages, oxidative status, pain perception or healing processes. Secondary outcomes that were analyzed included a number of complications, amputation, quality of life, satisfaction from the treatment process.

\section{Risk Factors for Peripheral Arterial Diseases}

There is a strong correlation between PAD development and type II diabetes. Intermediate claudication occurs twice more frequently among diabetic patients than among people without diabetes mellitus. ${ }^{7}$ However, the largest risk factor is insulin resistance. It raises PAD development risk by
$40-50 \%$. This applies also to non-diabetic patients. The course of the peripheral arterial disease appears to be more aggressive among diabetic patients. Distal symmetrical neuropathy can occur even at the early stage of PAD. Major amputations are performed five to ten times more frequently among diabetic patients. Hypertension and dyslipidemia are the following risk factors correlated with PAD. The most accurate predictor of PAD development has been identified as a ratio of total to high-density lipoprotein. ${ }^{8}$ Higher blood level of triglycerides (TG), very low-density lipoproteins (VLDL) and intermediate-density lipoproteins (IDL), as well as lower level of high-density lipoproteins (HDL), has been shown to be associated with PAD. The evidence shows correlation not only with PAD incidence but also with the progression of disease, intermediate claudication occurrence and systemic complications of PAD. The occurrence of intermediate claudication is twice more frequent among patients with a fasting cholesterol level above $270 \mathrm{mg} / \mathrm{dl}$. C-reactive protein (CRP) has been also shown to be associated with PAD. ${ }^{9}$ Having CRP in the highest quartile accounts for twice higher PAD development risk compared with the lowest quartile. Hyperviscosity and hypercoagulability are proven to be PAD risk factors. Among PAD patients, increased plasma level of fibrinogen and raised hematocrit level have been also reported. Hyperhomocysteinemia appears to be an independent risk factor for atherosclerosis. The prevalence of this condition among young PAD patients is as high as $30 \%$.

\section{Ozone Therapy}

Ozone therapy has been studied for more than a century. Medical $\mathrm{O}_{3}$, used to disinfect and treat disease, has been around for over 150 years and its effectiveness has been well documented. At the same time, opinions about this method are still divided. The uncertainty of ozone therapy might come from the toxicity of ozone $\left(\mathrm{O}_{3}\right)$ present in the atmosphere. Ozone produced by the breakage of pollutants and nitrous oxides by ultraviolet light is indeed irritant to the eyes and lungs. The exact toxicity level of ozone has not been established due to a great variance of individual sensitivity to the $\mathrm{O}_{3}$ exposure. ${ }^{10}$ This variability can be attributed to age, body mass index, physical fitness, as well as health problems such as asthma. The National Ambient Air Quality Standard states a daily maximum of 8-hour ozone exposure at the level of $80 \mathrm{ppb}$. It has been also shown that a 10-ppb ozone raise in the previous week results in a $0.52 \%$ increase in daily mortality and 
a $0.64 \%$ increase in cardiovascular and respiratory mortality. ${ }^{11}$ However, most of the time, at the Earth's surface, ozone occurs at the concentration of $20 \mu \mathrm{g} / \mathrm{m}^{3}$ and this level is completely safe for human beings. It is worth noting that what is dangerous for health is a repeated exposure to low doses of $\mathrm{O}_{3}$. Ozone toxicity does not apply to the controlled and proper administration of medical ozone. ${ }^{12}$ Ozone therapy is based on high doses in order to stimulate the immunology system. Numerous studies have proven that ozone therapy effects are consistent and the therapy is safe and does not cause side effects. The ozone therapy mechanism of action is based on the formation of reactive oxygen species (ROS) and lipids oxidation products (LOP). Fortunately, ROS disappear quickly, as they are short-term acting particles. LOPs are distributed throughout the tissues; therefore, only a few molecules can act on the organs. Therefore instead of causing harm, these particles stimulate antioxidant defense, as well as modify the immune system.

The first use of ozone was mainly with the purpose of treating infections and wounds. Ozone therapy has been shown to be very effective in bacterial infection of skin. ${ }^{13}$ Ozonated oil eliminated almost $100 \%$ of Staphylococcus aureus in 5 minutes, as well as almost 100\% of methicillin-resistant Staphylococcus aureus after 15 minutes. Ozone causes oxidation of phospholipids and lipoproteins of bacterial cell walls. ${ }^{12}$ Thus, ozone therapy disrupts the integrity of bacterial cell walls. Similarly, ozone damages the viral capsid causing inactivation of viruses. ${ }^{14}$ Moreover, viral reproductive cycle is broken as peroxidation precludes the virus-to-cell contact. ${ }^{12}$ Ozone has been also proven to cause irreversible damage to viral DNA. ${ }^{3}$ Ozone therapy used for fungal infections is based on the mechanism of ozone inhibition of cell growth at certain stages. $^{12}$

The knowledge of medical use of oxygen has been broadly expanding since 1929, when a book titled "Ozone and Its Therapeutic Actions" was published. This publication covered more than hundred diseases that could be treated by the ozone therapy. Ozone's hemodynamic and anti-inflammatory properties are now well documented. Through proper administration (never via inhalation) of precise and high doses (in comparison to the environmental contamination), ozone brings benefits as it decreases blood cholesterol, improves glycemic index, as well as stimulates antioxidant defence. ${ }^{12}$ The therapeutic dosage ranges from 10 to $80 \mu \mathrm{g} / \mathrm{mL} .^{15}$ It has been shown that the immune system is altered by the ozone. The production of interferon is greatly stimulated by ozone therapy with the parameter of $30-55 \mu \mathrm{g} / \mathrm{mL}$. The release of tumor necrosis factor and interleukin-2 is also stimulated by ozone. Moreover, the oxygen-ozone therapy is a successful treatment of hypoxic and ischemic syndromes through modulation of tissue oxygenation. This particular effect seems to be most important in relation to peripheral artery disease. A recently published review has also confirmed a mechanism of action through which ozone might be involved in recovering metabolism altered by chronic diseases such as cardiovascular disease. ${ }^{16}$

\section{Evidence of Ozone Therapy Effectiveness in vitro Studies}

The detailed results of the ozone therapy effectiveness are shown in Table 1. One of the studies concerning the in vitro effect of the ozone therapy tested platelet aggregation changes due to the ozone administration. ${ }^{17}$ The purpose of the other study was to identify structural and functional cell changes that occurred due to the oxygenozone therapy. ${ }^{18}$ The methodology of these two studies varied a lot, as the ozone concentration used to observe cell structure changes ranged from $1 \mu \mathrm{g} \mathrm{O} / \mathrm{mL}$ to $20 \mu \mathrm{g}$ $\mathrm{O}_{3} / \mathrm{mL}$, while the concentration used to analyze the effect on platelet aggregation ranged from $20 \mu \mathrm{g} \mathrm{O} / \mathrm{mL}$ to $80 \mu \mathrm{g}$ $\mathrm{O}_{3} / \mathrm{mL}$. However, the time of the $\mathrm{O}_{2}-\mathrm{O}_{3}$ therapy with the methodology of higher concentrations was much shorter (30 seconds) compared with the time of lower concentrations of ozone therapy (10 minutes). The presence of a control group in both of these studies allows the conclusion to be drawn that observed effects are actually due to ozone. It has been shown that the oxygen-ozone therapy directly causes an increase of PDGF (platelet-derived growth factor) and TGF- $\beta 1$ (transforming growth factorbeta 1). These two molecules play an important role in healing processes. The most suitable parameters of the $\mathrm{O}_{2}$ $-\mathrm{O}_{3}$ therapy to exert the effect on PDGF and TGF $\beta 1$ molecules have been proposed as $40-80 \mu \mathrm{g} \mathrm{O}_{3} / \mathrm{mL}$. Stimulation of IL-8 (interleukin 8) release has been also attributed to the oxygen-ozone therapy; however, this effect required a longer time as a synthesis of IL- 8 was firstly inhibited by ROS scavengers. Though, even high concentration ozone therapy did not manage to change the overall oxidative status of cells. It was also shown that the $\mathrm{O}_{2}-\mathrm{O}_{3}$ therapy does not affect cell proliferation as well as cell viability. The effect of ozone on the cell adhesion is dependent on the concentration. At the dose of $10 \mu \mathrm{g}$ 
Table I In vitro Studies Concerning Ozone Therapy

\begin{tabular}{|c|c|c|c|c|c|}
\hline \multirow{2}{*}{$\begin{array}{l}\text { Author, } \\
\text { Year } \\
\text { Costanzo } \\
\text { et al, } \\
2015^{18}\end{array}$} & \multirow{2}{*}{$\begin{array}{l}\text { Aim of the Study } \\
\text { Investigation of the } \\
\text { effects of low ozone } \\
\text { concentrations on structural } \\
\text { and functional cell features }\end{array}$} & \multirow{2}{*}{ 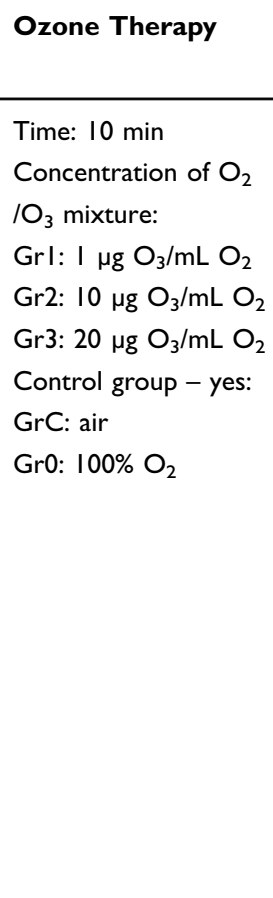 } & \multicolumn{3}{|l|}{ Results } \\
\hline & & & $\begin{array}{l}\text { Cell viability and } \\
\text { proliferation: } \\
\text { no significant } \\
\text { differences } \\
\text { Cell adhesion: } \\
\uparrow \text { GrI vs GrC \& Gr0 } \\
\text { after } 30 \text { min and } \\
\text { after I hour; after } 2 \\
\text { h, } 4 \text { h, } 6 \text { h: no } \\
\text { significant difference } \\
\uparrow \text { Gr2 vs GrC \& Gr0 } \\
\downarrow \text { Gr3 vs GrC \& Gr0 } \\
\text { Cell flattening: } \\
\text { - no significant } \\
\text { difference between } \\
\text { GrC, Gr0, Grl, Gr3 } \\
\text { - percentage of flat } \\
\text { cells significantly } \\
\text { higher in Gr2 }\end{array}$ & $\begin{array}{l}\text { Mitochondrial } \\
\text { membrane potential: } \\
\text { no significant } \\
\text { difference } \\
\text { Distribution of } \\
\text { protein in the cell: } \\
\text { no significant } \\
\text { difference } \\
\text { Pyruvate } \\
\text { dehydrogenase } \\
\text { complex: } \\
\text { no significant } \\
\text { difference }\end{array}$ & $\begin{array}{l}\text { Morphological features: } \\
\text { Grl: smaller } \\
\text { mitochondria with lower } \\
\text { amount of cristae } \\
\text { Gr2: well developed \& } \\
\text { abundant cristae } \\
\text { Gr2: higher density of } \\
\text { fibrillary component in } \\
\text { both nucleoplasm and } \\
\text { nucleolus } \\
\text { Gr2: higher content of } \\
\text { Hsp70 protein in } \\
\text { nucleolus (vs GrC), lower } \\
\text { content of Hsp70 protein } \\
\text { in cytoplasm (vs GrC) } \\
\text { Gr2: higher content of } \\
\text { mtHsp70 protein inside } \\
\text { mitochondria (vs GrC) }\end{array}$ \\
\hline $\begin{array}{l}\text { Valacchi } \\
\text { et al, } \\
1999^{17}\end{array}$ & $\begin{array}{l}\text { Investigation whether the use } \\
\text { of heparin or citrate added to } \\
\text { blood, before ozonation, } \\
\text { affects the release of platelet } \\
\text { factors differently }\end{array}$ & $\begin{array}{l}\text { Before ozonation, } \\
\text { blood samples were } \\
\text { enriched with either } \\
\text { heparin or citric acid. } \\
\text { Time: } 30 \mathrm{sec} \\
\text { Concentration of } 3 \% \\
\mathrm{O}_{2} / \mathrm{O}_{3} \text { mixture: } \\
\text { GrI: } 20 \mu \mathrm{g} \mathrm{O}_{3} / \mathrm{mL} \mathrm{O}_{2} \\
\text { Gr2: } 40 \mu \mathrm{O}_{3} / \mathrm{mL} \mathrm{O}_{2} \\
\text { Gr3: } 80 \mu \mathrm{g} \mathrm{O}_{3} / \mathrm{mL} \mathrm{O}_{2} \\
\text { Control group }- \text { yes: } \\
\text { GrC: air } \\
\text { Gr0: } 100 \% \mathrm{O}_{2}\end{array}$ & $\begin{array}{l}\text { Total antioxidant } \\
\text { status: } \\
\text { no significant } \\
\text { difference } \\
\text { Protein thiol group: } \\
\downarrow \text { Grl + heparin, } \\
\text { Gr2 + heparin, Gr3 } \\
+ \text { heparin } \\
\downarrow \text { Gr2 + heparin vs } \\
\text { Gr2 + citric acid } \\
\downarrow \text { Gr3 + heparin vs } \\
\text { Gr3 + citric acid } \\
\text { The higher dose of } \\
0_{3} \text {, the larger } \\
\text { reduction. } \\
\text { Thiobarbituric acid } \\
\text { reactive substances: } \\
\uparrow \text { Grl, Gr2, Gr3 (no } \\
\text { significant difference } \\
\text { between heparin and } \\
\text { citric acid) } \\
\text { The higher dose of } \\
0_{3} \text {, the larger } \\
\text { increase. }\end{array}$ & $\begin{array}{l}\text { PDGF: } \\
\text { - larger increase for } \\
\text { heparin + GrC, Grl, } \\
\text { Gr2, Gr3 heparin vs } \\
\text { citric acid at all times } \\
\text { - for citric acid } \\
\text { increase only in Gr3 } \\
\text { at time point of Ih, } \\
\text { 2h, } 4 \text { h; in Gr2 at } \\
\text { time point of } 4 \mathrm{~h} \\
\text { - for heparin } \\
\text { increase in all groups } \\
\text { at all time points } \\
\text {-the higher dose of } \\
0_{3} \text {, the larger } \\
\text { increase of PDGF } \\
\text { TGF- } \beta \mathrm{I} \text { : } \\
\text { - heparin: significant } \\
\text { increase for Grl, } \\
\text { Gr2, Gr3 at Ih; Gr2 } \\
\& \text { Gr3 at } 2 \mathrm{~h} ; \mathrm{Gr} \text {, } \\
\text { Gr2 \& Gr3 at } 4 \mathrm{~h} \\
\text {-heparin: the higher } \\
\text { dose of } 0_{3} \text {, the } \\
\text { larger increase of } \\
\text { TGF } 3 \mathrm{I} \\
\text { - citric acid: no } \\
\text { significant difference }\end{array}$ & $\begin{array}{l}\text { IL-8: } \\
-\uparrow \text { for GrI + heparin, } \\
\text { Gr2 + heparin, Gr3 + } \\
\text { heparin for } 4 \mathrm{~h} \\
-\uparrow \text { for Gr2 + citric acid, } \\
\text { Gr3 + citric acid for } 4 \mathrm{~h} \\
\text { - the higher dose of } 0_{3} \text {, } \\
\text { the large increase of IL-8 } \\
\text { at time point of } 4 \mathrm{~h} \\
\text { TXB2: } \\
\text { - } \uparrow \text { for Gr2 \& Gr3 at Ih \& } \\
2 \mathrm{~h} \text { (both heparin and } \\
\text { citric acid) } \\
\text { - at } 4 \mathrm{~h} \uparrow \text { for GrI, Gr2, } \\
\text { Gr3 (both heparin and } \\
\text { citric acid) }\end{array}$ \\
\hline
\end{tabular}

Abbreviations: Gr, group of cells; IL-8, interleukin 8; PDGF, platelet-derived growth factor; TGF- $\beta$ I, transforming growth factor beta I; TXB2, thromboxane B2. 
$\mathrm{O}_{3} / \mathrm{mL}$ adhesion is significantly improved, while exposure to $20 \mu \mathrm{g} \mathrm{O}_{3} / \mathrm{mL}$ resulted in lowered adhesion and flatting ability. It is worth noting the lowest used concentration exerted positive effects; however, they were very shorttermed. Concerning the side effects of the $\mathrm{O}_{2}-\mathrm{O}_{3}$ therapy, Costanzo et al study provided important evidence of minimal ROS production due to the low concentration of ozone therapy. ${ }^{18}$ Actually, small increase in ROS level stimulates remodeling of cell structure and positive changes of mitochondria. Ten-microgram $\mathrm{O}_{3} / \mathrm{mL}$ induced reorganization of cytoskeletal elements, increased mitochondrial cristae length and prompted positive response of higher expression of proteins to engage in numerous mitochondria functions. Thus, a concentration of $10 \mu \mathrm{g} \mathrm{O}_{3} / \mathrm{mL}$ seems to be the most appropriate for inducing structural and functional cell changes.

From the in vitro studies, it can be concluded that the ozone therapy exerts a positive effect on the platelet aggregation, cell remodeling, cytoskeletal elements organization, as well as mitochondria structure. At the same time, the $\mathrm{O}_{2}-\mathrm{O}_{3}$ therapy does not cause negative changes of the cell oxidative status.

\section{Evidence of Oxygen-Ozone Therapy Effectiveness in Animal Studies}

Animal studies provide evidence of the $\mathrm{O}_{2}-\mathrm{O}_{3}$ therapy effectiveness; furthermore, they give in-depth knowledge about the mechanism of the occurred changes. All the experiments presented in this review (Table 2) were performed on rats. Three of the four studies were concerned with hypoxia condition, while one study examined hypertension. All studies had a control group, the sample size varied from 20 to 30 rats. The highest dose of $3 \% \mathrm{O}_{3} / \mathrm{O}_{2}$ mixture was used in the study tested oxygen-ozone therapy effectiveness on hypertension. ${ }^{19}$ This was also the longest study, as intraperitoneal ozone was administered for 10 days. As a result of the $\mathrm{O}_{2}-\mathrm{O}_{3}$ therapy with the above parameters, the direct cardiovascular effect of ozone was observed. Systolic as well as diastolic blood pressure and mean arterial pressure were lowered by ozone. The mechanism of this observation involves decreasing level of serum endothelin-1 (ET-1) and increasing levels of serum renin and nitric oxide (NO). However, it is worth noting that oxygen-ozone therapy did not manage to lower blood pressure to normative level. In the case of examining protective effect from acute myocardial infarction 3\% $\mathrm{O}_{3} / \mathrm{O}_{2}$, a mixture was administered at the lowest dose
$(100-300 \mu \mathrm{g} / \mathrm{kg})$ and it was given only once - an hour prior to ischemia/reperfusion procedure. ${ }^{20}$ Despite this, the $\mathrm{O}_{2}-\mathrm{O}_{3}$ mixture managed to decrease myocardial infarction. The protective effect was observed due to the stimulation of endothelial nitric oxide synthase-dependent endothelial progenitor cells (EPCs) recruitment. EPCs are known to induce angiogenesis. ${ }^{21}$ Koca et al study as well as Ozkan et al study provides an information about the mechanism of the $\mathrm{O}_{2}-\mathrm{O}_{3}$ therapy effect on oxidative status in relation to hypoxia state of bone and skeletal muscle. ${ }^{22,23}$ The oxygen-ozone therapy has been shown to exert protective effect from hypoxia of bone by stimulating antioxidant enzymes activity, superoxide dismutase and glutathione peroxidase. At the same time, parameters of oxidative damage, lipid peroxidation and protein carbonyl were significantly decreased by intraperitoneal administration of four doses of $0.7 \mathrm{mg} / \mathrm{kg}$ ozone mixture. Ozkan et al found similar results, but in skeletal muscle tissue. ${ }^{23}$ Additionally, this study investigated creatinine kinase and aspartate aminotransferase serum level (tissue damage indicators), which has been found as decreased due to ozone preconditioning.

From the animal studies, it can be concluded that the ozone therapy is an effective method in hypertension, as well as ozone preconditioning exerts protective effect during myocardial infarction and hypoxia state of bone and skeletal muscles.

\section{Evidence of Ozone Therapy Effectiveness in Clinical Trials}

Effectiveness of the ozone therapy has been also examined in the clinical trials, which are presented in Table 3. The number of participants taking part in the described studies varied from seven to 151 . Methods of ozone administration involved direct intravenous infusion, autohemotherapy, ozone bath, as well as rectal insufflation accompanied by the use of ozonated oil. The number of sessions in the clinical trials varied from three sessions to 20 sessions, while the whole treatment lasted from 1 week up to 22 weeks. Two of the described studies were concerned with cerebral low perfusion syndromes. Clavo et al examined the effect of the $\mathrm{O}_{2}-\mathrm{O}_{3}$ therapy on cerebral blood flow. ${ }^{24}$ The oxygen-ozone therapy was found to cause an increase in diastolic velocity in arteries, accompanied by decreased vascular resistance and rheological improvement. The observation of the correlation between the stimulation of arterial blood flow and the initial values has been made. 


\begin{tabular}{|c|c|c|}
\hline \multirow[b]{3}{*}{ 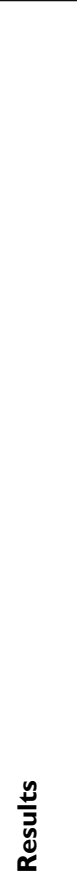 } & 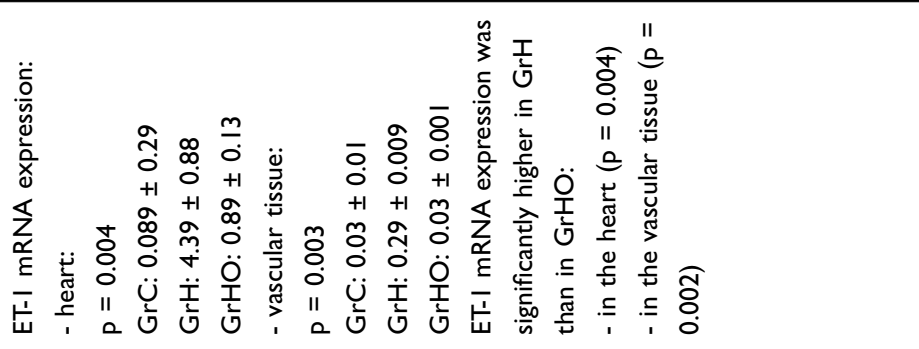 & 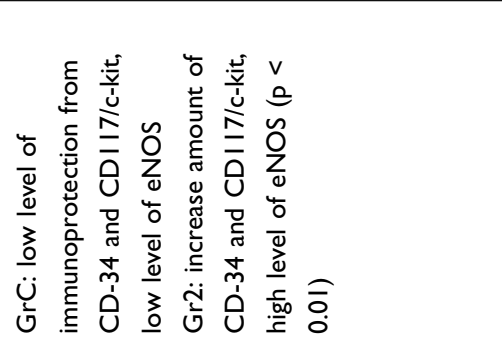 \\
\hline & 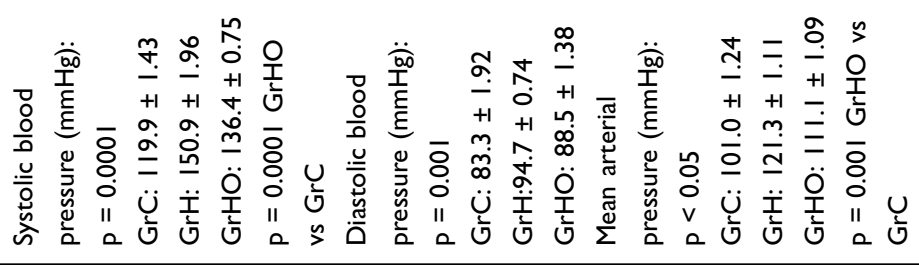 & 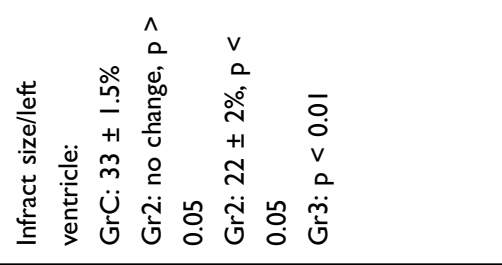 \\
\hline & 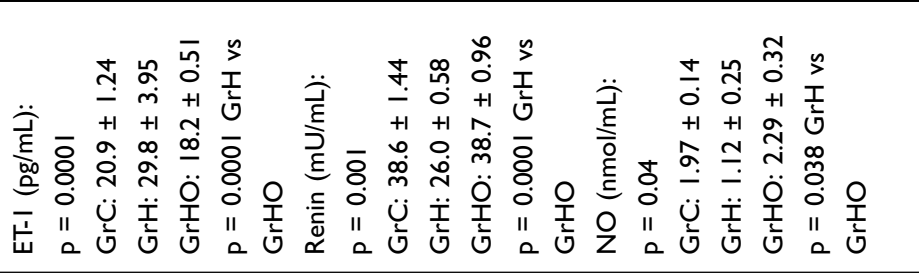 & 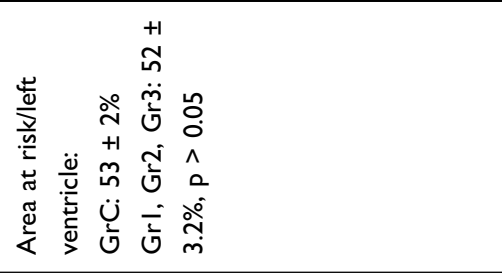 \\
\hline 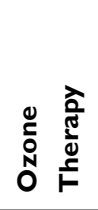 & 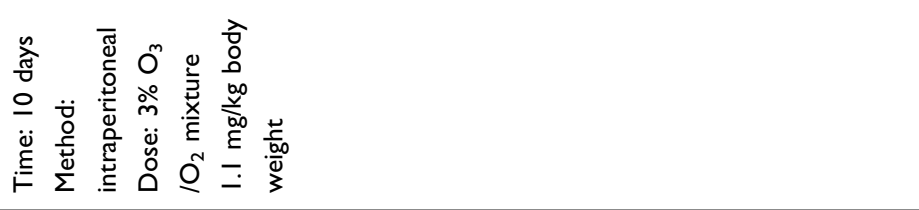 & 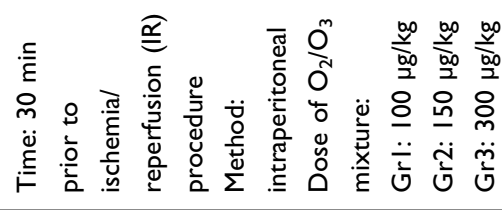 \\
\hline 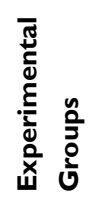 & 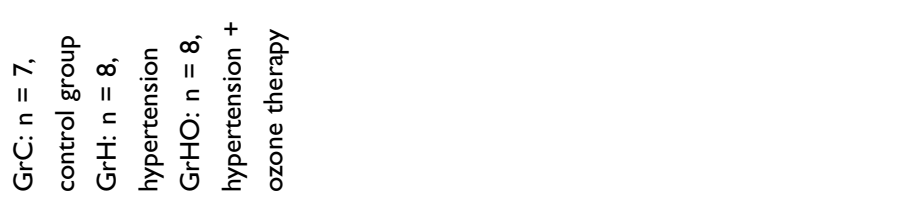 & 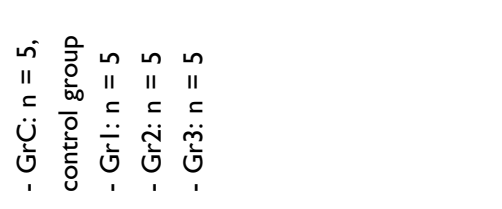 \\
\hline 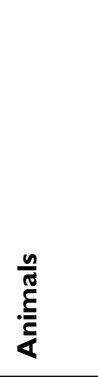 & 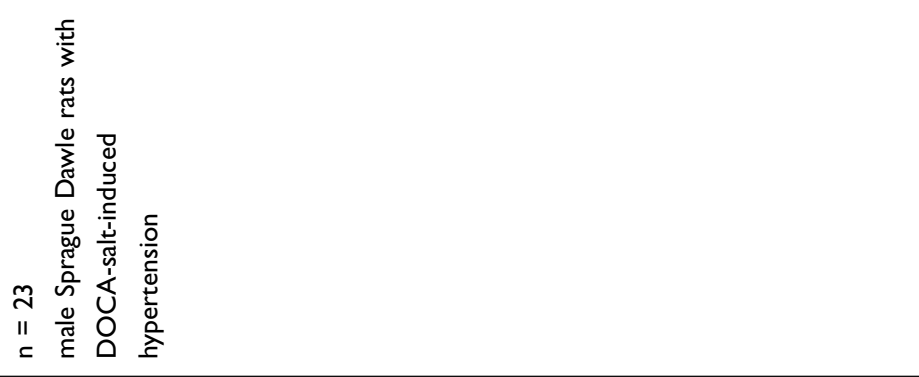 & 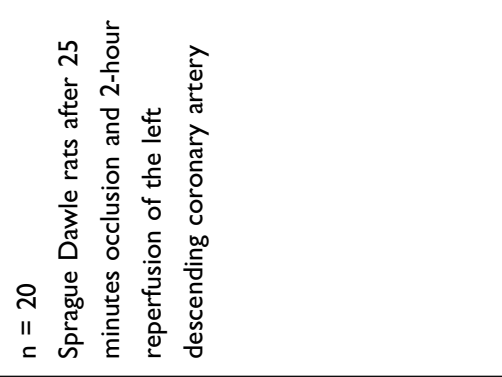 \\
\hline 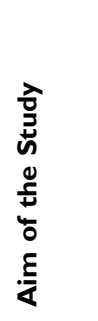 & 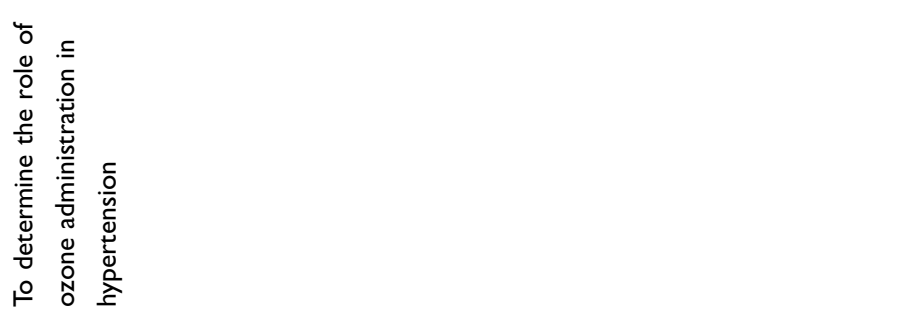 & 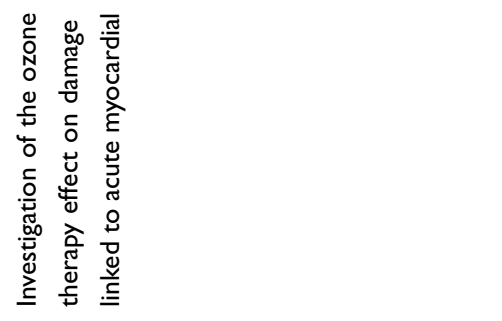 \\
\hline 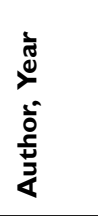 & 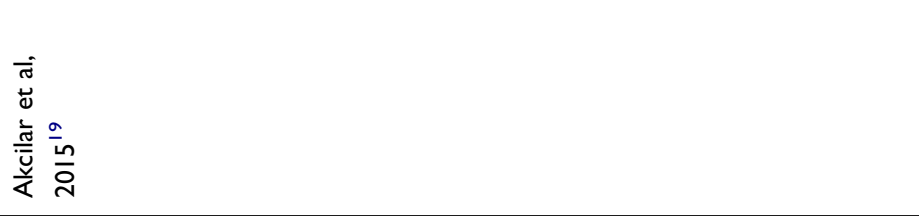 & 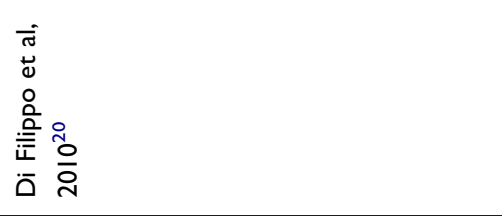 \\
\hline
\end{tabular}




\begin{tabular}{|c|c|}
\hline 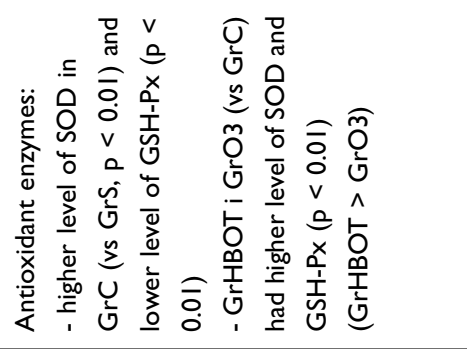 & 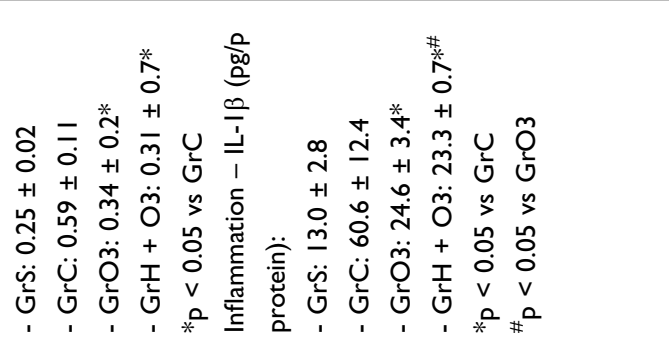 \\
\hline 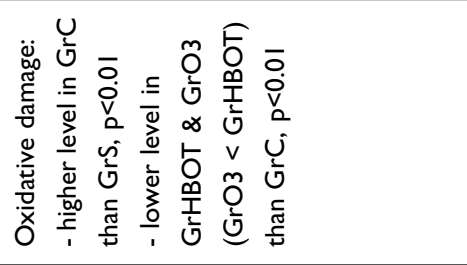 & 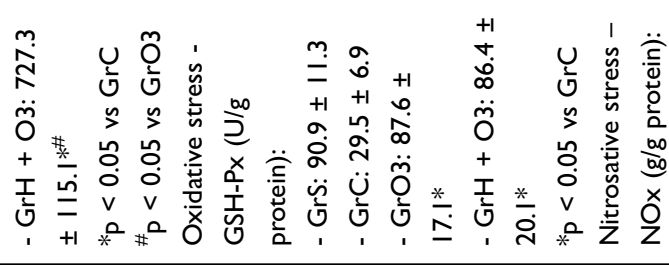 \\
\hline 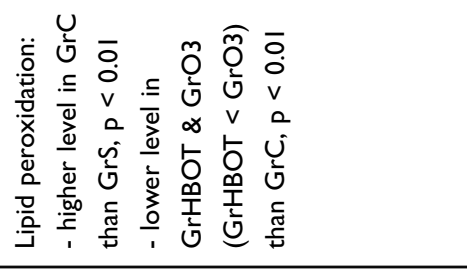 & 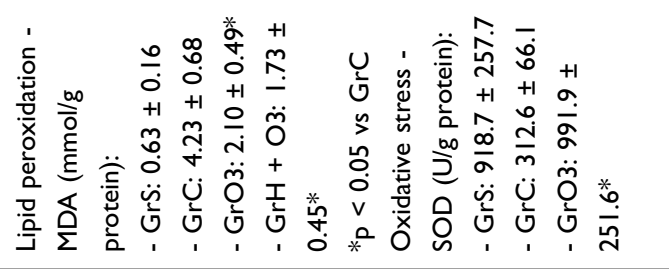 \\
\hline 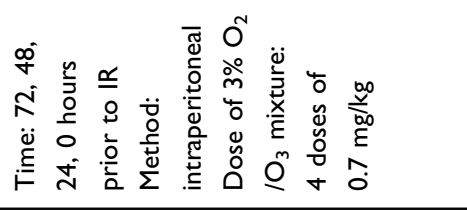 & 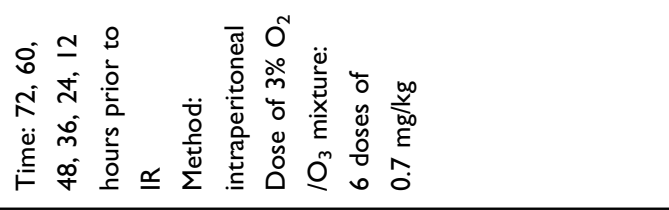 \\
\hline 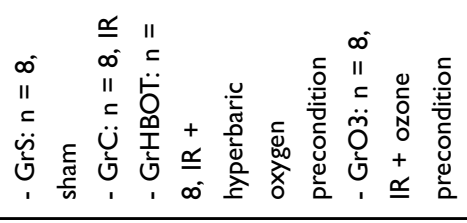 & 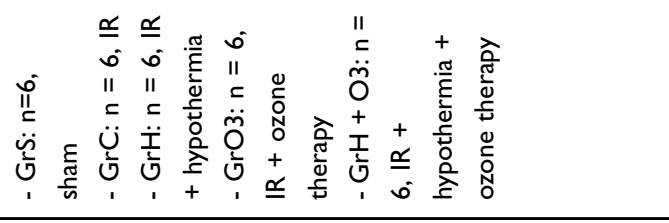 \\
\hline 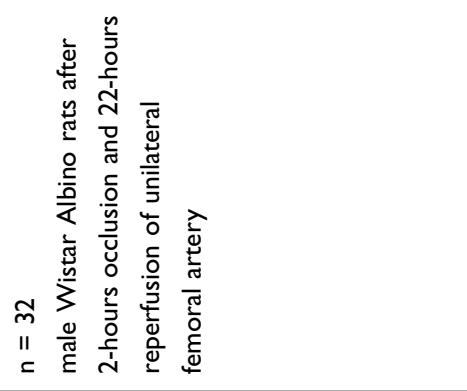 & 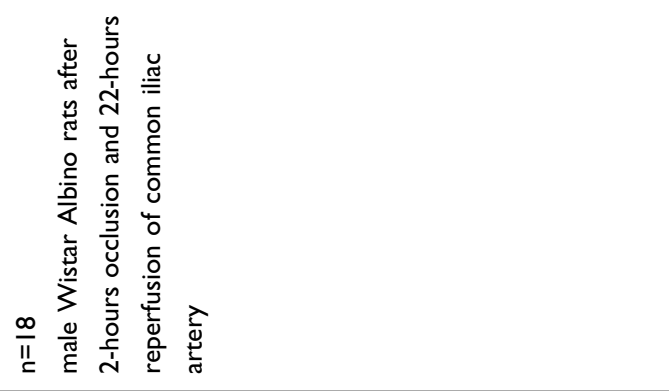 \\
\hline 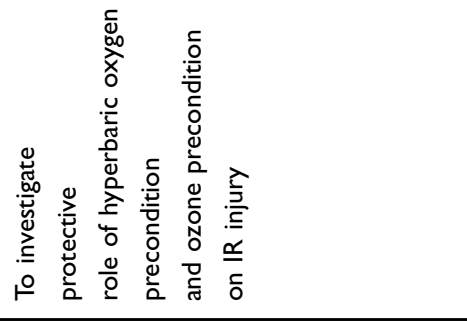 & 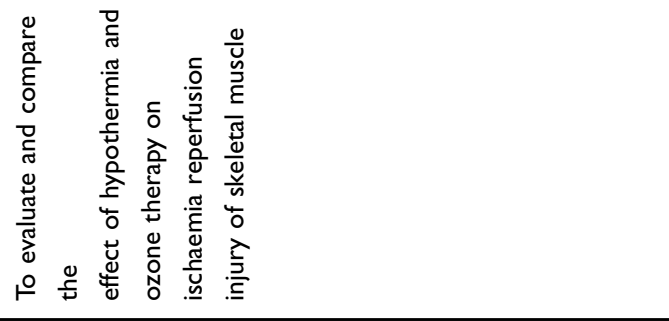 \\
\hline 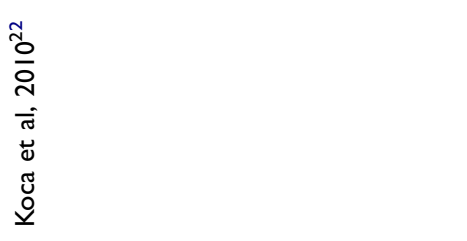 & 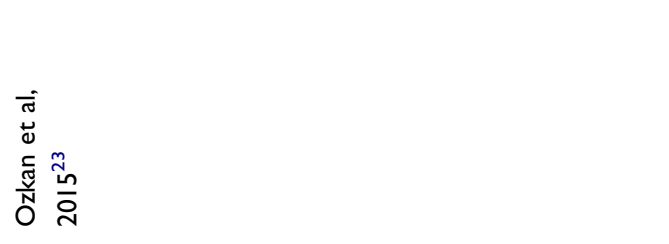 \\
\hline
\end{tabular}




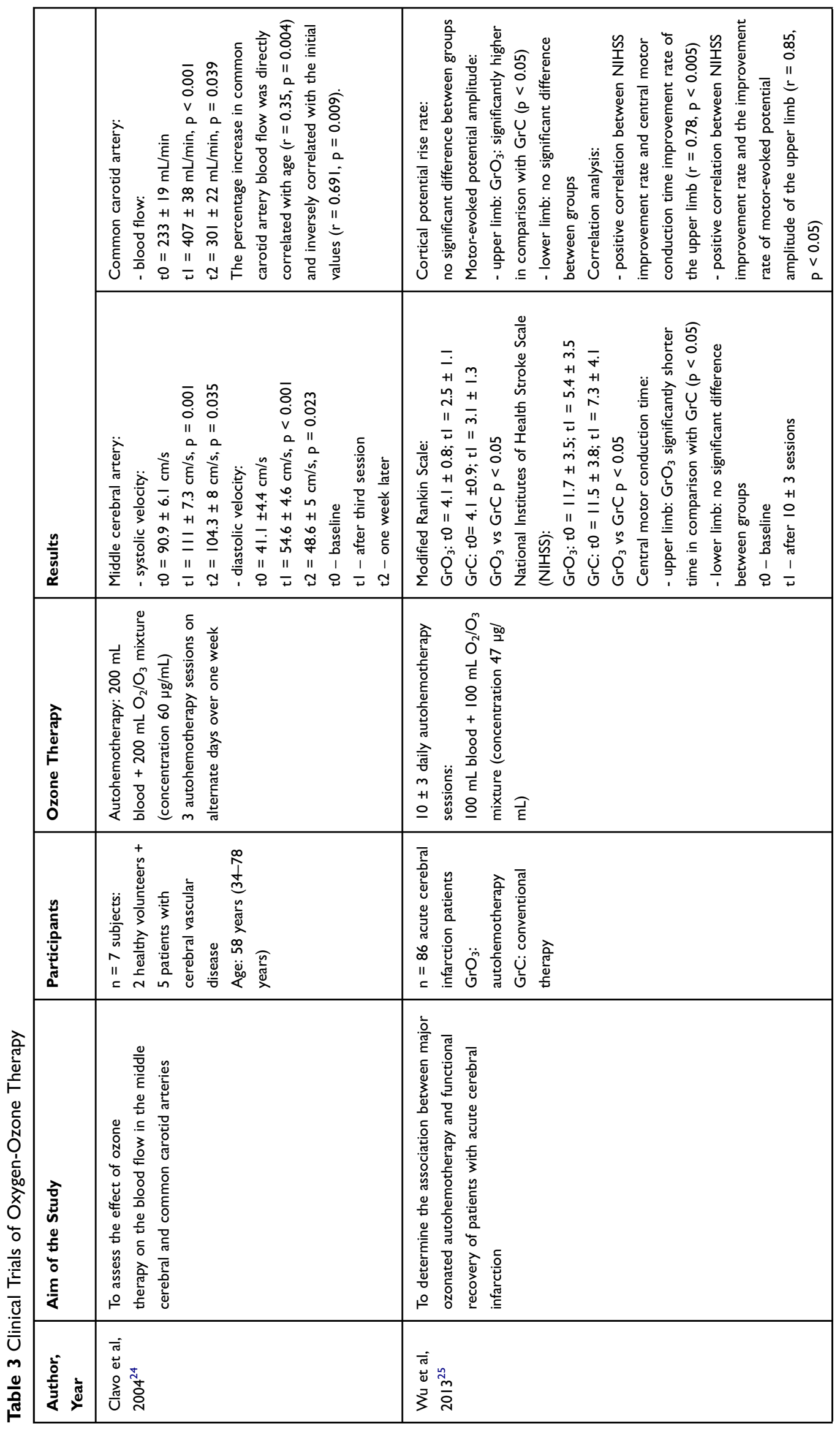




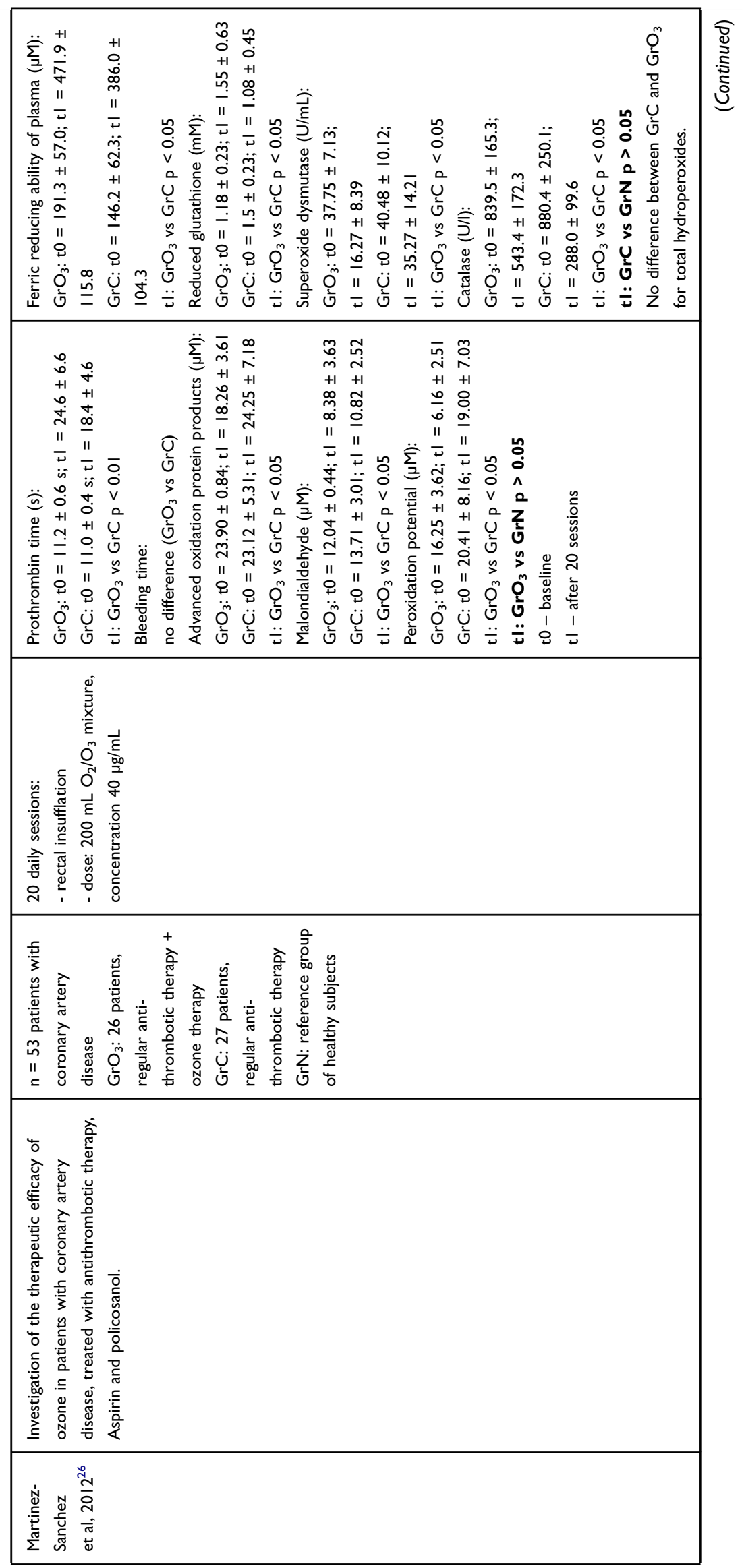




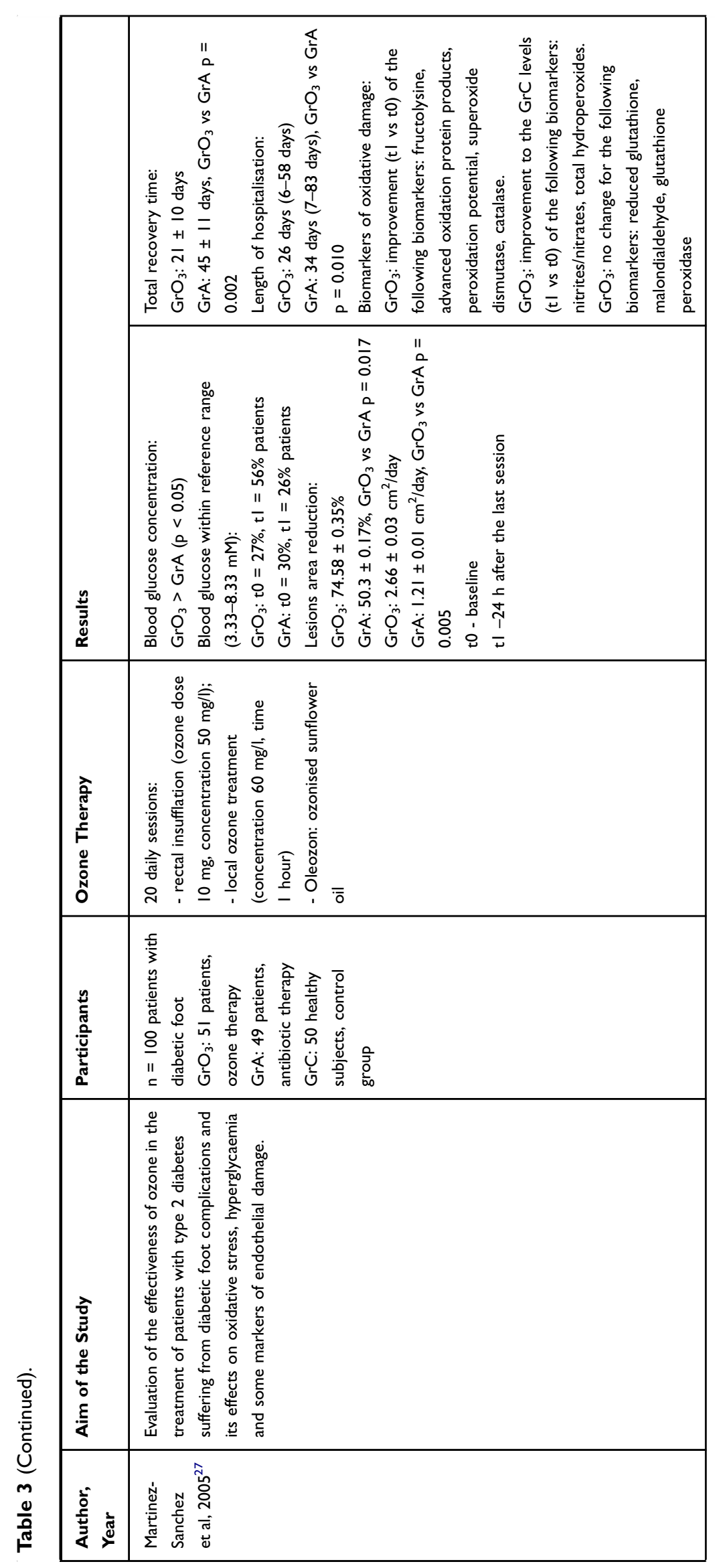




\begin{tabular}{|c|c|}
\hline 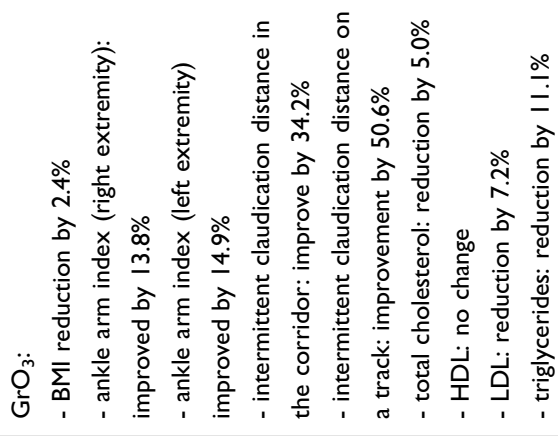 & 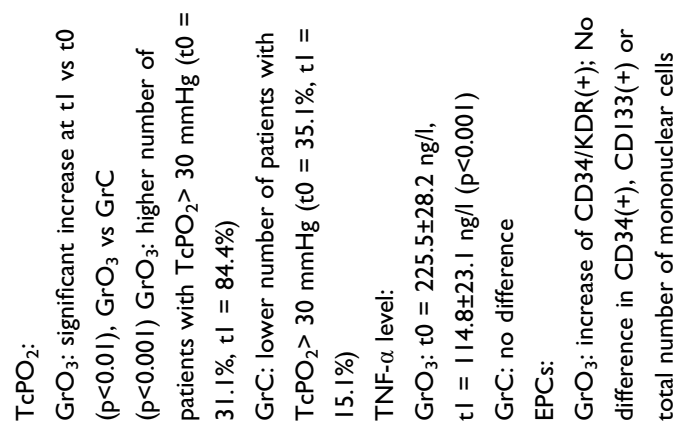 \\
\hline 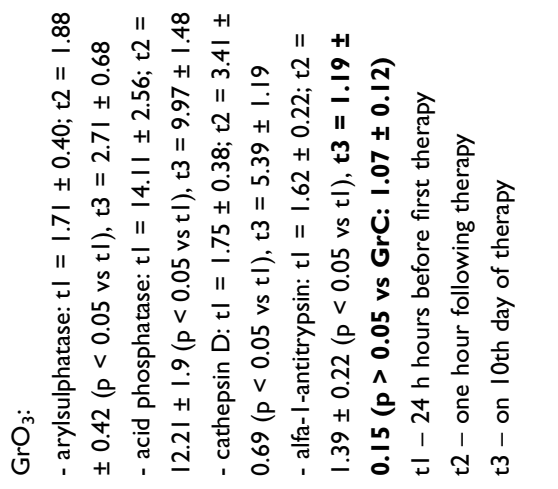 & 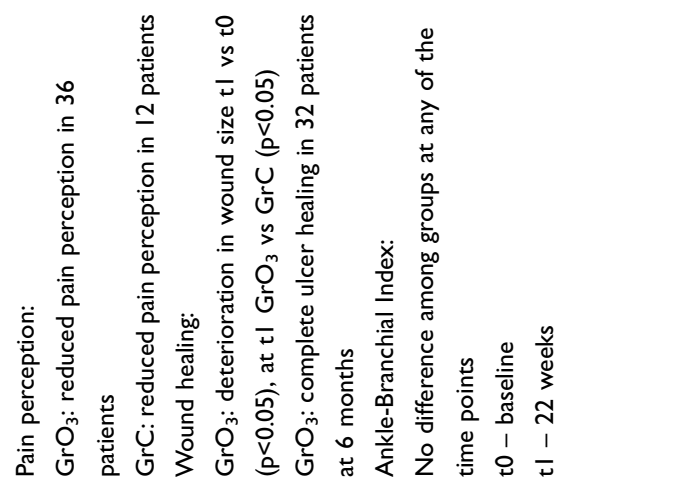 \\
\hline 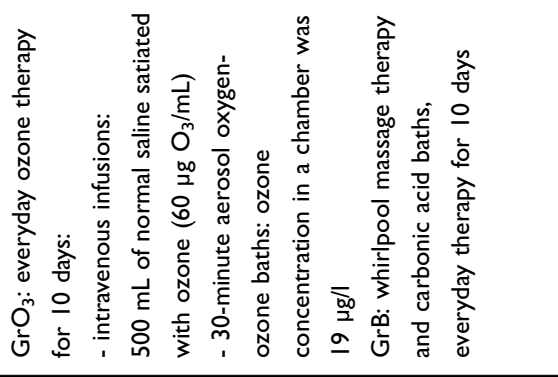 & 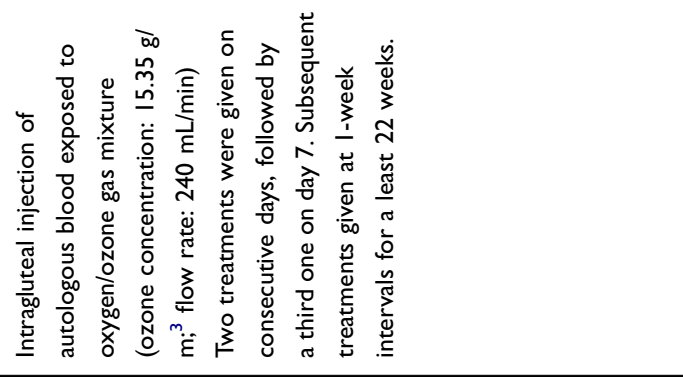 \\
\hline 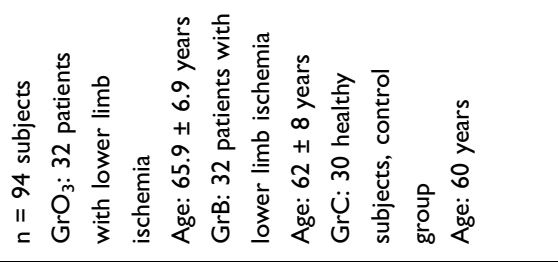 & 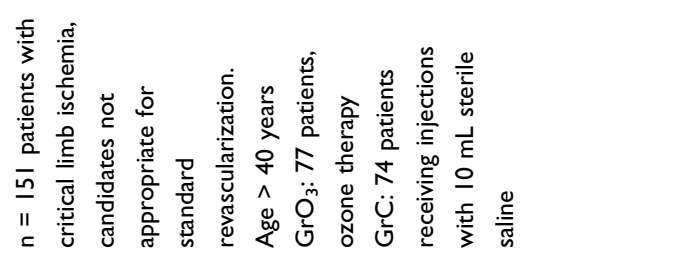 \\
\hline 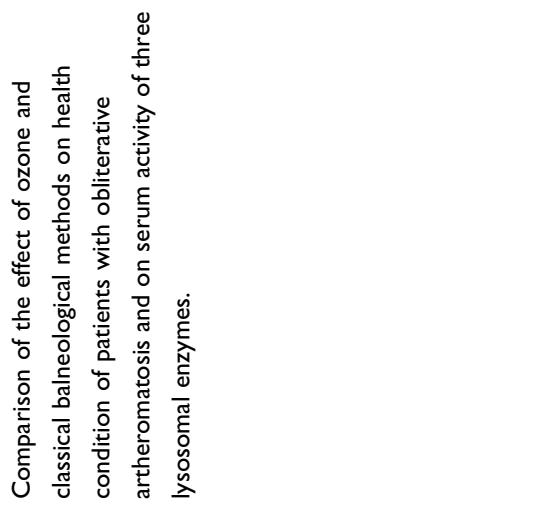 & 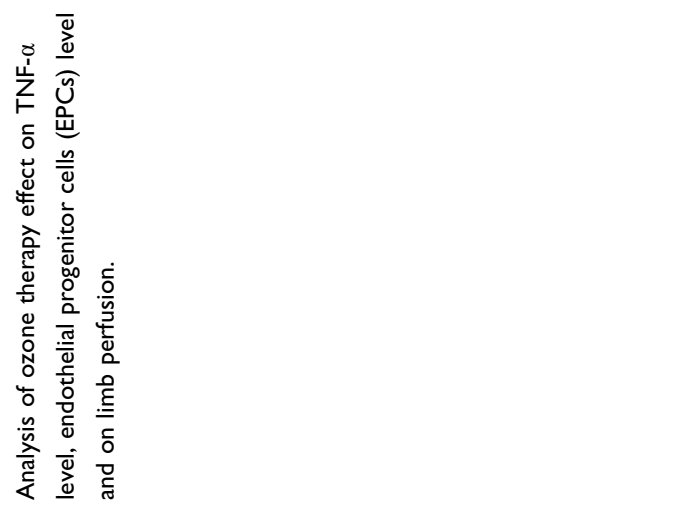 \\
\hline 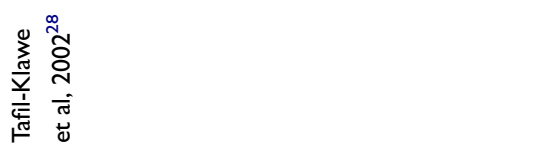 & 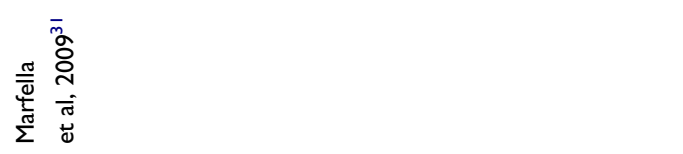 \\
\hline
\end{tabular}




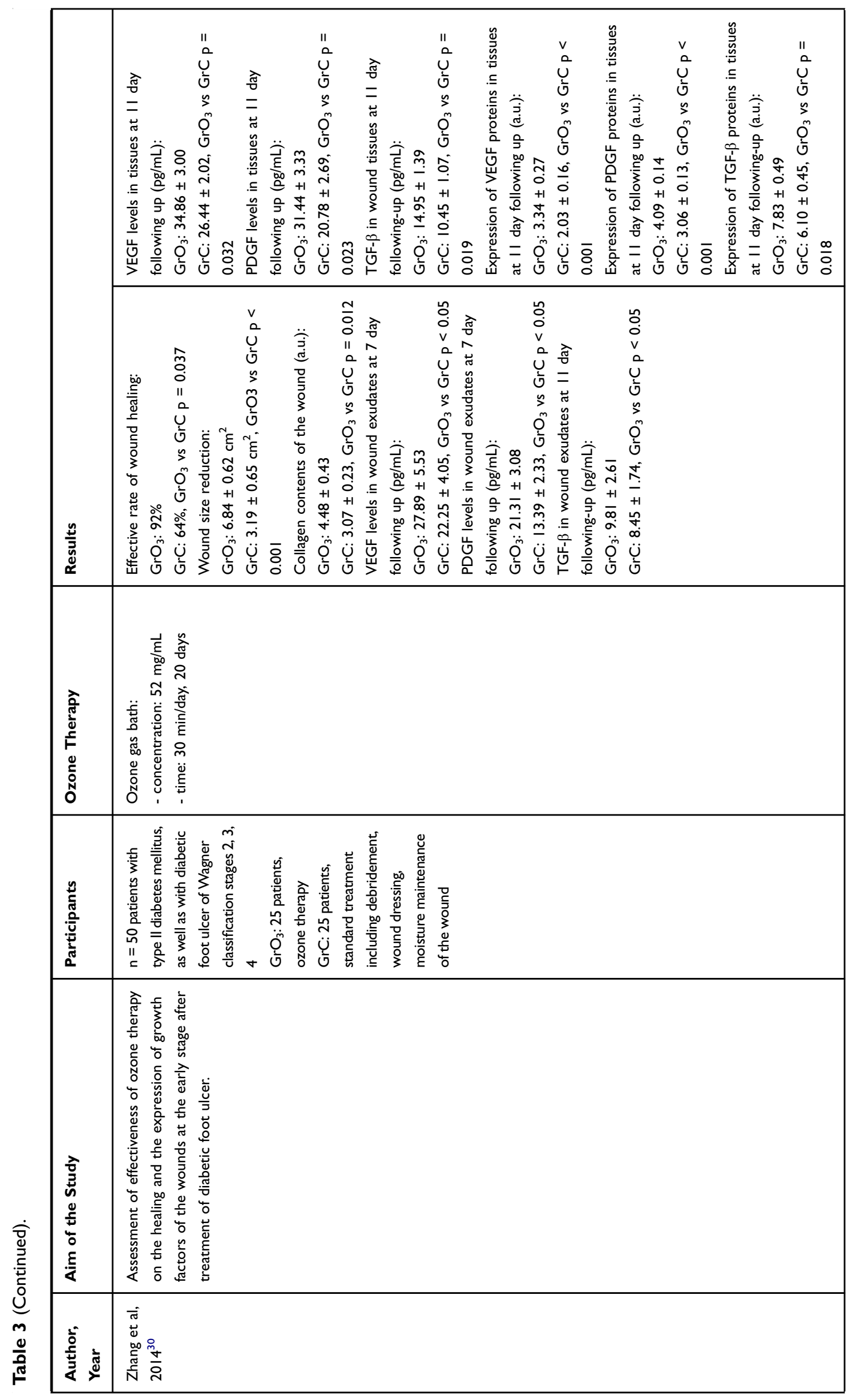




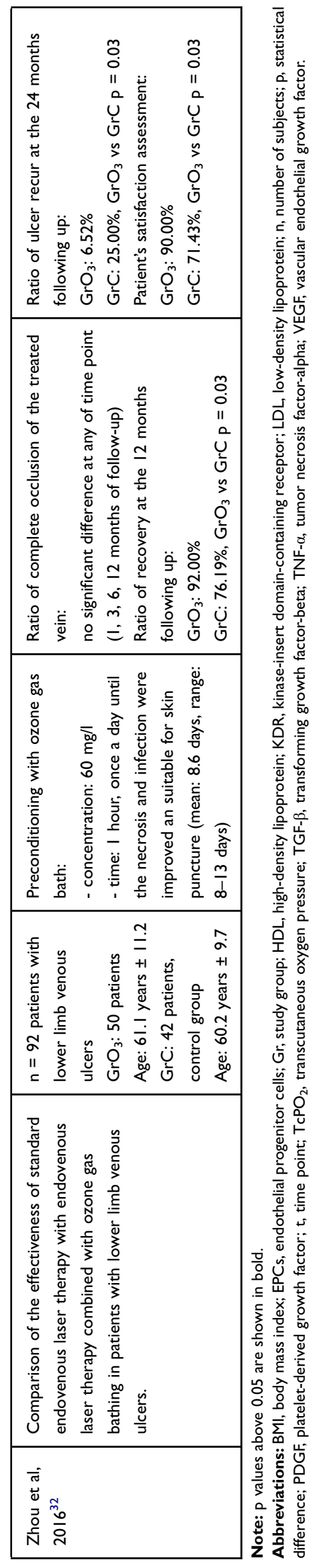

Tissues with higher hypoxia state are more responsive to the $\mathrm{O}_{2}-\mathrm{O}_{3}$ therapy. What is more, a greater effect was also seen in older patients. Wu et al study provided the evidence that patients with acute cerebral infarction may gain advantage of oxygen-ozone therapy in the form of a better motor function recovery. ${ }^{25}$ The mechanism enabling previously mentioned effects of the $\mathrm{O}_{2}-\mathrm{O}_{3}$ therapy involves upregulation of vasoactive substances release, enhanced erythrocyte flexibility as well as improved blood rheology. The oxygen-ozone therapy results in the rise of adenosine triphosphate (ATP) and 2.3-diphosphoglycerate content in the red blood cells. Ozone also promotes pentose phosphate pathway reactions that result in the release of nicotinamide adenine dinucleotide phosphate. This molecule is crucial for erythrocyte membrane integrity. Moreover, ozone lowers blood viscosity and stimulates hydrogen dioxide release that breaks down thrombus, thus microcirculation may be improved. Blood clotting is also affected due to the change of blood platelet polymerization. Finally, ozone stimulates basal metabolism by upregulating tricarboxylic acid and a stimulating fat catabolism. As a result, fatty materials on the vessel wall may be removed.

Ozone effect on hemostasis was also the main topic of Martinez-Sanchez et al. ${ }^{26}$ Among 53 patients with coronary artery disease, 20 everyday sessions of rectal insufflation were performed. Platelet aggregation has been inhibited due to the platelet activation factor, collagen and adenosine diphosphate changes. The oxygen-ozone therapy activates adenosine $A_{2}$ receptor in the platelet causing enhancing platelets adenylate cyclase and rising level of platelet cyclic-3',5'-adenosine monophosphate. Moreover, the $\mathrm{O}_{2}-\mathrm{O}_{3}$ therapy has been shown to down-regulate oxidative stress and inflammatory processes. Markers such as degree of monocyte activation, dityrosine, advanced glycation end products, neopterin, inflammatory cytokines were decreased in the response to ozone. Total antioxidant capacity, measured by ferric reducing ability of plasma (FRAP) parameter, has been increased. FRAP parameter is a marker combining changes in the antioxidant activity of multiple compounds. The observed change exerted a major effect on oxidative status indicating a shift to the status of low reactive oxygen species production and an increase in $\mathrm{H}_{2} \mathrm{O}_{2}$ detoxification. Ozone can also enhance antioxidant status by inhibiting the production of reactive oxygen species through xanthine/xanthine oxidase pathway. Therefore, an effective stimulation of oxidative defense by the $\mathrm{O}_{2}-\mathrm{O}_{3}$ 
therapy seen in the in vitro studies is confirmed by the clinical trials.

Overproduction of superoxide by the mitochondrial electron-transport chain as well as disturbed antioxidant status are the processes highly correlated with a state of hyperglycemia. Patients with type II diabetes suffering from diabetic foot complication were a study group of another clinical trial examining the therapeutic effect of ozone. $^{27}$ It has been demonstrated that the $\mathrm{O}_{2}-\mathrm{O}_{3}$ therapy not only decreases hyperglycemia but also brings blood glucose concentration back to the healthy reference range. This observation was attributed to the ozone effect on the antioxidant system, as well as enhanced insulin sensitivity. Hydrogen peroxide causes significantly reduced glucose uptake in adipocytes. This process may be reversed by ozone, as it reduces the level of hydrogen peroxide and thus stimulates phosphatidylinositol 3 kinase activity and promotes migration of glucose transport 4 translocation from the intracellular compartment to the cellular surface. Ozone enhances metabolic actions preventing glycogen depletion, ATP depletion and providing constant availability of free glucose. Furthermore, oxygen-ozone therapy restored to normal reference values the $\mathrm{NO}^{-2} / \mathrm{NO}^{-3}$ ratio, a marker of nitric oxide. The most important finding of Martinez-Sanchez et al is the fact that $\mathrm{O}_{2}-\mathrm{O}_{3}$ therapy is effective in reducing the amount of amputations needed among the patients as well as decreasing the extent of the amputation. $^{27}$ Moreover, patients have recovered faster and have a better perceived quality of life due to the oxygen-ozone therapy.

Patients with lower limb ischemia however not being as a result of diabetes complications but due to the obliterative atheromatosis were a study group of Tafil-Klawe et al clinical trial. ${ }^{28}$ The mechanism of lower limb ischemia complications involves the stimulated activity of acid phosphatase. Through normalization of lysosome membranes, reduction in phagocytosis of monocytes and macrophages, as well as through a decrease in the activity of acid phosphate, the $\mathrm{O}_{2}-\mathrm{O}_{3}$ therapy prevents cell autolysis and limits tissue damage. The oxygen-ozone therapy has been shown to have clinical effectiveness, as the intermittent claudication distance prolonged by $50.6 \%$.

One of the most concerning complications of lower limb ischemia is the formation of ulceration. Diabetic foot ulcers can be characterized by delayed wound healing, prolonged closure time, very low collagen deposition, as well as decreased expression of endogenous growth factors in the wound. ${ }^{29}$ Zhang et al investigated the effectiveness of ozone gas bathing in relation to wound healing and expression of growth factors such as vascular endothelial growth factor (VEGF), TGF- $\beta$ and PDGF. ${ }^{30}$ The ozone therapy significantly stimulated wound healing, so that wound reduction occurred much more quickly. This effect can be explained by the higher content of collagen and growth factors, that has been observed in this study. Enhanced wound healing as well as reduced pain perception were the effects also observed in the clinical study concerning critical limb ischaemia. ${ }^{31}$

Zhou et al also examined the effectiveness of the oxygen-ozone therapy as a supplementary method of lower limb venous ulcers treatment. ${ }^{32}$ One of the most important findings of this study is that infection of the ulcer has been reduced due to the $\mathrm{O}_{2}-\mathrm{O}_{3}$ therapy. As it was stated previously, ozone disrupts the integrity of bacterial cell walls, thus demonstrating antimicrobial properties. Zhou et al provide clinical evidence that the oxygen-ozone therapy may be a successful infection treatment among diabetic patients as well. ${ }^{32}$ The observation of higher recovery ratio, higher patient's satisfaction and lower recurrence rate has been made when the patients were preconditioned with ozone gas bath. It is worth noting that just seven to 13 sessions were enough to exert long-term effects. This study provides evidence for the effectiveness of ozone gas bathing, which is a non-invasive method and a treatment showing high compliance. Ozone gas bathing is also a good method for elderly patients and patients in poor condition that make them unsuitable candidates for surgery.

Among all of the described studies, the most important effects of the $\mathrm{O}_{2}-\mathrm{O}_{3}$ therapy in relation to peripheral artery diseases were the following: improved tissue perfusion resulting in reduced hypoxia state; better rheology; better glycemic control; enhanced lipid metabolism; enhanced anti-oxidant defense; faster healing processes; neurovascular protective effect; reduced inflammation; reduced sensation of pain. An economic evaluation performed for neuroinfectious diabetic foot has shown that oxygenozone therapy may reduce treatment costs by one quarter compared with the standard antibiotic therapy. Taking all of those observations together the $\mathrm{O}_{2}-\mathrm{O}_{3}$ therapy appears to be an effective adjunctive therapy in preventing PAD complications such as amputation or occurrence of major cardiovascular events.

\section{Conclusions}

The consequence of risk factor modulation by the oxygenozone therapy, as evidenced in this paper, appears to be 
very effective in terms of cardiovascular event prevention. Heart attack, stroke and major cardiovascular diseases are events resulting from deterioration over time. These changes involve arterial stenosis, elevated blood pressure, dyslipidemia, poor glycemic control, disturbed oxidative status, long-term inflammation. The oxygen-ozone therapy has been shown as an effective method of improving all of the above conditions.

Chronic ulceration is a major problem among PAD patients. It is a frequent cause of disturbed microcirculation, swelling and perivascular edema. Long healing as well as frequent recurrence of the ulcers may eventually result in non-healing venous ulcers and amputation. It has been proven that the $\mathrm{O}_{2}-\mathrm{O}_{3}$ therapy supports traditional ulcer treatment so that better therapy outcomes are achieved.

The oxygen-ozone therapy is well tolerated by patients, they experience less pain and their satisfaction from the treatment process increases when the $\mathrm{O}_{2}-\mathrm{O}_{3}$ therapy is included. All of those effects and the fact of lower risk of amputation makes the oxygen-ozone therapy effective in improving the quality of life of PAD patients. The therapy appears to have no adverse events or side effects, as none have been reported in the clinical trials. What is more, it may reduce standard treatment costs. In comparison with standard antibiotic therapy, as much as $25 \%$ of diabetic foot treatment costs can be saved. Easy clinical protocols allow the implementation of the oxygen-ozone therapy into the usual care of PAD patients. The $\mathrm{O}_{2}-\mathrm{O}_{3}$ therapy appears to be a promising treatment method especially for older PAD patients and patients, who are not eligible for standard revascularization.

\section{Disclosure}

The authors report no conflicts of interest in this work.

\section{References}

1. Fowkes FG, Rudan D, Rudan I, et al. Comparison of global estimates of prevalence and risk factors for peripheral artery disease in 2000 and 2010: a systematic review and analysis. Lancet. 2013;382 (9901):1329-1340. doi:10.1016/S0140-6736(13)61249-0

2. Hirsch AT, Criqui MH, Treat-Jacobson D, et al. Peripheral arterial disease detection, awareness, and treatment in primary care. JAMA. 2001;286(11):1317-1324. doi:10.1001/jama.286.11.1317

3. Fitzpatrick E, Holland OJ, Vanderlelie JJ. Ozone therapy for the treatment of chronic wounds: a systematic review. Int Wound J. 2018;15(4):633-644. doi:10.1111/iwj.12907

4. Azarpazhooh A, Limeback H. The application of ozone in dentistry: a systematic review of literature. J Dent. 2008;36(2):104-116. doi:10.1016/j.jdent.2007.11.008
5. Bocci V, Zanardi I, Huijberts MS, Travagli V. Diabetes and chronic oxidative stress. A perspective based on the possible usefulness of ozone therapy. Diabetes Metab Syndr. 2011;5(1):45-49. doi:10.1016/ j.dsx.2010.05.014

6. Norgren L, Hiatt WR, Dormandy JA, et al. Inter-society consensus for the management of peripheral arterial disease (TASC II). Eur J Vasc Endovasc Surg. 2007;33(Suppl 1):S1-75. doi:10.1016/j.ejvs. 2006.09.024

7. Muntner P, Wildman RP, Reynolds K, Desalvo KB, Chen J, Fonseca V. Relationship between HbA1c level and peripheral arterial disease. Diabetes Care. 2005;28(8):1981-1987. doi:10.2337/diacare. 28.8.1981

8. Senti M, Nogues X, Pedro-Botet J, Rubies-Prat J, Vidal-Barraquer F. Lipoprotein profile in men with peripheral vascular disease. Role of intermediate density lipoproteins and apoprotein $\mathrm{E}$ phenotypes. Circulation. 1992;85(1):30-36. doi:10.1161/01.CIR.85.1.30

9. Ridker PM, Stampfer MJ, Rifai N. Novel risk factors for systemic atherosclerosis: a comparison of C-reactive protein, fibrinogen, homocysteine, lipoprotein(a), and standard cholesterol screening as predictors of peripheral arterial disease. JAMA. 2001;285 (19):2481-2485. doi:10.1001/jama.285.19.2481

10. Swanson TJ, Chapman J. Ozone Toxicity. Treasure Island (FL): StatPearls Publishing; 2020.

11. Bell ML, McDermott A, Zeger SL, Samet JM, Dominici F. Ozone and short-term mortality in 95 US urban communities, 1987-2000. JAMA. 2004;292(19):2372-2378. doi:10.1001/jama.292.19.2372

12. Elvis AM, Ekta JS. Ozone therapy: a clinical review. J Nat Sci Biol Med. 2011;2(1):66-70. doi:10.4103/0976-9668.82319

13. Song M, Zeng Q, Xiang Y, et al. The antibacterial effect of topical ozone on the treatment of MRSA skin infection. Mol Med Rep. 2018;17(2):2449-2455. doi:10.3892/mmr.2017.8148

14. Sunnen G. MERS, SARS, and Emerging Coronaviruses: Theoretical Considerations and a Proposal for Critical Care Parenteral Oxygen/ Ozone Therapy. 2014.

15. Bocci V, Di Paolo N. Oxygen-ozone therapy in medicine: an update. Blood Purif. 2009;28(4):373-376. doi:10.1159/000236365

16. Di Mauro R, Cantarella G, Bernardini R, et al. The biochemical and pharmacological properties of ozone: the smell of protection in acute and chronic diseases. Int J Mol Sci. 2019;20(3):E634. doi:10.3390/ ijms20030634

17. Valacchi G, Bocci V. Studies on the biological effects of ozone: 10 . Release of factors from ozonated human platelets. Mediators Inflamm. 1999;8(4-5):205-209. doi:10.1080/09629359990360

18. Costanzo M, Cisterna B, Vella A, et al. Low ozone concentrations stimulate cytoskeletal organization, mitochondrial activity and nuclear transcription. Eur J Histochem. 2015;59(2):2515. doi:10. 4081/ejh.2015.2515

19. Akcilar R, Akcer S, Simsek H, Akcilar A, Bayat Z, Genc O. The effect of ozone on blood pressure in DOCA-salt-induced hypertensive rats. Int J Clin Exp Med. 2015;8(8):12783-12791.

20. Di Filippo C, Luongo M, Marfella R, et al. Oxygen/ozone protects the heart from acute myocardial infarction through local increase of eNOS activity and endothelial progenitor cells recruitment. Naunyn Schmiedebergs Arch Pharmacol. 2010;382(3):287-291. doi:10.1007/ s00210-010-0545-2

21. Rodriguez-Losada N, Garcia-Pinilla JM, Jimenez-Navarro MF, Gonzalez FJ. Endothelial progenitor cells in cell-based therapy for cardiovascular disease. Cell Mol Biol (Noisy-Le-Grand). 2008;54(1):11-23.

22. Koca K, Yurttas Y, Bilgic S, et al. Effect of preconditioned hyperbaric oxygen and ozone on ischemia-reperfusion induced tourniquet in skeletal bone of rats. J Surg Res. 2010;164(1):e83-89. doi:10.1016/ j.jss.2010.06.030

23. Ozkan H, Ekinci S, Uysal B, et al. Evaluation and comparison of the effect of hypothermia and ozone on ischemia-reperfusion injury of skeletal muscle in rats. J Surg Res. 2015;196(2):313-319. doi:10. 1016/j.jss.2015.01.053 
24. Clavo B, Catala L, Perez JL, Rodriguez V, Robaina F. Ozone therapy on cerebral blood flow: a preliminary report. Evid Based Complement Alternat Med. 2004;1(3):315-319. doi:10.1093/ecam/neh039

25. Wu X, Li Z, Liu X, et al. Major ozonated autohemotherapy promotes the recovery of upper limb motor function in patients with acute cerebral infarction. Neural Regen Res. 2013;8(5):461-468. doi:10.3969/j.issn.1673-5374.2013.05.010

26. Martinez-Sanchez G, Delgado-Roche L, Diaz-Batista A, PerezDavison G, Re L. Effects of ozone therapy on haemostatic and oxidative stress index in coronary artery disease. Eur J Pharmacol. 2012;691(1-3):156-162. doi:10.1016/j.ejphar.2012.07.010

27. Martinez-Sanchez G, Al-Dalain SM, Menendez S, et al. Therapeutic efficacy of ozone in patients with diabetic foot. Eur J Pharmacol. 2005;523(1-3):151-161. doi:10.1016/j.ejphar.2005.08.020

28. Tafil-Klawe M, Wozniak A, Drewa T, et al. Ozone therapy and the activity of selected lysosomal enzymes in blood serum of patients with lower limb ischaemia associated with obliterative atheromatosis. Med Sci Monit. 2002;8(7):Cr520-525.
29. Kushmakov R, Gandhi J, Seyam O, et al. Ozone therapy for diabetic foot. Med Gas Res. 2018;8(3):111-115. doi:10.4103/2045-9912.24 1076

30. Zhang J, Guan M, Xie C, Luo X, Zhang Q, Xue Y. Increased growth factors play a role in wound healing promoted by noninvasive oxygen-ozone therapy in diabetic patients with foot ulcers. Oxid Med Cell Longev. 2014;2014:273475. doi:10.1155/2014/ 273475

31. Marfella R, Luongo C, Coppola A, et al. Use of a non-specific immunomodulation therapy as a therapeutic vasculogenesis strategy in no-option critical limb ischemia patients. Atherosclerosis. 2010;208(2):473-479. doi:10.1016/j.atherosclerosis.2009.08.005

32. Zhou YT, Zhao XD, Jiang JW, Li XS, Wu ZH. Ozone gas bath combined with endovenous laser therapy for lower limb venous ulcers: a randomized clinical trial. J Invest Surg. 2016;29 (5):254-259. doi:10.3109/08941939.2016.1149637

\section{Publish your work in this journal}

Therapeutics and Clinical Risk Management is an international, peerreviewed journal of clinical therapeutics and risk management, focusing on concise rapid reporting of clinical studies in all therapeutic areas, outcomes, safety, and programs for the effective, safe, and sustained use of medicines. This journal is indexed on PubMed Central, CAS,
EMBase, Scopus and the Elsevier Bibliographic databases. The manuscript management system is completely online and includes a very quick and fair peer-review system, which is all easy to use. Visit http://www.dovepress.com/testimonials.php to read real quotes from published authors 